\title{
DATA SYNCHRONISATION AND COST REDUCTION USING API IN CUSTOMER RELATIONSHIP MANAGEMENT
}

Research has shown that 51\% of all ERP implementations involve some kind of problems in business operations during the "go live" phase. Despite all the efforts to increase efficiency and improve business processes, many organizations come to a conclusion that once they move to the new ERP system they are not able to perform some of the basic business processes (both in the data migration phase and operational procedures), such as issuing goods from the warehouse. The ERP implementations are too often accompanied by technical and organizational issues that may cause problems in the functioning of a business system. As organizational issues are more frequently the cause of the problem, it is crucial to accurately perform the business processes analysis phase, as well as the final testing.

Based on the analysis of the ERP (Enterprise Resource Planning), CRM (Customer Relationship Management) and SCM (Supply Chain Management) e-business models of the largest producers of software applications, the bottlenecks and shortcomings typical of the implementation of these models were identified in a select sample of clients and it has been established that there are certain inconsistencies and programme problems between the company information system (IS) and the implemented ERP/CRM or SCM models. The identified problems served as the basis for designing and programming an application programming interface (API) aimed at addressing certain application needs of the companies, i.e. the inadequate synchronization of databases and other IT resources. The API has been designed and programmed with a view to resolving the problems with inconsistencies and synchronization and reducing business operations costs. It has been tested as a pilot application on ISs of selected companies that apply the ERP/CRM business support systems. This work describes the ERP/CRM database synchronization process and tests the quality of the API solution based on a programmed web survey, i.e. on the statistical processing of the obtained results of the survey which documents the quality of the proposed solutions and confirms the successful implementation of the API solution.

Keywords: ERP, CRM, interface-IFACE, web services, API-Application Programming Interface, business processes, DBMS, databases

\footnotetext{
* $\quad$ MSc, BSc in Electrical Engineering, Director at OSA - Računarski inženjering doo zeljko.tomic@osa.rs

** Ph.D., BSc in Electrical Engineering, Executive Director at PTT Serbia Public Enterprise mihailo.jovanovic@ptt.rs
} 


\section{Introduction}

Both CRM and ERP are geared towards the same goal: increasing company profitability. However, designers/programmers of the two systems have different approaches to achieving this goal. ERP is primarily aimed at cost reduction and business process optimization. On the other hand, $\mathrm{CRM}^{1}$ approaches profitability from the point of increasing sales and maintaining customer relations. ${ }^{2}$ It is well known that the costs of selling products and services to new customers are up to six times higher than is the case with the existing customers. There is room for improvement and development of relations with customers at all levels, from the sales force to the executives, which leads to higher sales volumes, consumer and brand loyalty and a higher level of satisfaction of customers, i.e. to lower operative costs of dealing with the consumers.

It is for these reasons that the ERP systems are often referred to as "backoffice systems" since they support the processes not necessarily visible to customers (procurement, production planning, order tracking, inventory management, etc.), whereas the CRM systems are called "front-office systems, which implies that they support the activities surrounding the interaction with customers.

An integration of ERP with CRM may ensure a dramatic return of investment ${ }^{3}$. If nothing else, this can help avoid double data entry in the systems, e.g. customer contact details and data on products and services ${ }^{4}$. While ERP is focused on utilizing the data about customers and their accounts in the process of invoicing and delivery, CRM uses the same data from lead generation, to potential customer monitoring and sales opportunities, to sales and support.

Figure 1 shows the activities in a sales cycle and the support provided by ERP and CRM. The overlaps between the two systems are obvious, as is the possibility for some activities to be performed in both ERP and CRM. Just like good integration of the two systems can lead to significant savings and optimisation of processes, bad integration leads to doubling the data, creating inconsistencies between the systems and increasing, rather than decreasing the costs of exploitation ${ }^{5}{ }^{6}$.

1 [13] Jovanović, M., Rankov S. (2012): Primena elektronskog poslovanja u upravljanju složenim sistemima, ISBN 9786-7038-054-7, COBISS.SR-ID 191422220, Published by the Post of Serbia Public Enterprise, 44

2 [28] Tuzhilin, A. (2012):Customer relationship management and Web mining: the next frontier. Data Mining And Knowledge Discovery,24(3, SI), 584-612. doi:10.1007/s10618-012-0256-z

3 [3] Bradford Marianne (2015): Modern ERP, Select, Implement \& use today's advanced business systems, Raleigh, NC, 156

4 [32] Yajun Zeng (2010): Risk Management for Enterprise Resource Planning System Implementations in Project Based Firms, 9

5 [14] Kalakota\& Robinson (2001):E-Business 2.0: Roadmap for Success, ISBN-10: 0-201-72165-1, ISBN-13: 978-0-201-72165-2, 125, 131

6 [21] Rashid, Hussain, \& Patrick, (2002):Enterprise Resource Planning: Global Opportunities \& Challenges, ISBN 1-930708-36-X (cloth), eISBN 1-59140-025-2, 215) 
Figure 1: Activities in a sales cycle and the support provided by ERP and CRM.

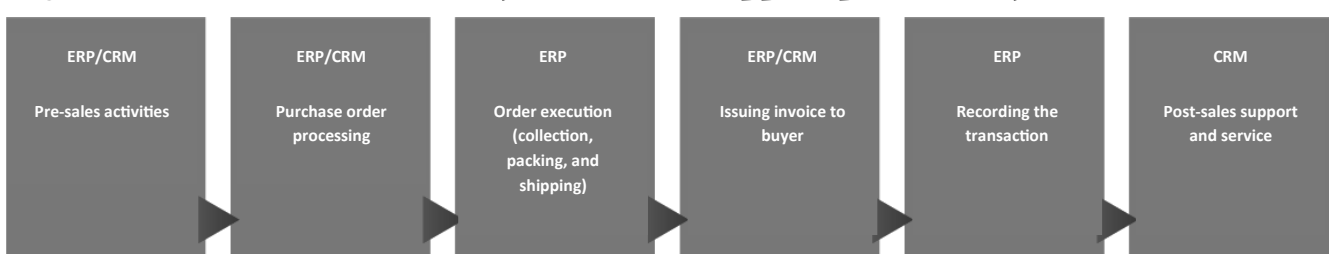

Source: [3]

Figure 2: Components of the business applications architecture

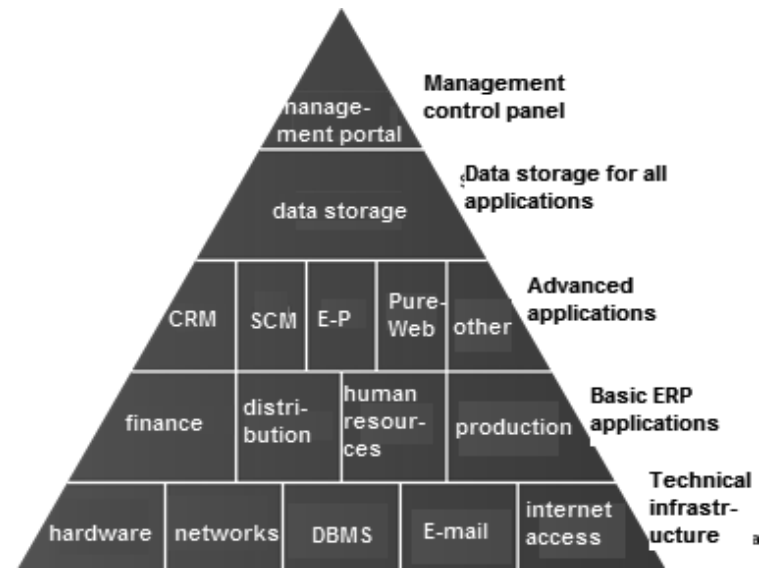

Source: [23] Shields Murrell, E-Business and ERP, Rapid Implementation and Project Planning, John Wiley and Sons Inc., Copyright 2001.)

The CRM and ERP systems are usually obtained and implemented separately and at different times. Quite often they are purchased from different vendors and producers and implemented by different teams.

As a rule, the CRM and ERP systems contain separate databases ${ }^{7}$ even if they come from the same manufacturer.

Such separately kept databases also lead to separate basic records (identifiers), which primarily relate to business partners and items and services. This may create problems with updating and maintaining consistency of the data within the information system of a company.

The CRM and ERP systems usually overlap in certain segments of business processes (e.g. orders, order confirmations, pro forma invoices, etc.), thus potentially creating redundant information and documents.

[15] Langer Arthur M. : Analysis and Design of Information Systems, Third Edition, Library of Congress Control Number: 2007928317 ISBN 978-1-84628-654-4 e-ISBN 978-1-84628-655-1, 127, 176 
More often than not, CRM and ERP also differ in terms of technology, both by their vertical architectures and with regard to the $\mathrm{DBMS}^{8}$ and $\mathrm{API}^{9}$ support.

\section{An analysis of the implementation of the existing solutions}

\subsection{Level of customisation}

As few as $9 \%$ of companies implement the ERP solutions without any adjustments, while as many as $25 \%$ of the projects involve extensive adjustment or complete customization (Table 1).

Table 1: Customization level of ERP solutions ${ }^{10}$

\begin{tabular}{|l|c|}
\hline \multicolumn{1}{|c|}{ Level of customization } & $\%$ surveyed \\
\hline Minor customization (1 - 10\% of the code) & $31 \%$ \\
\hline Some customization (11 - 25\% of the code) & $35 \%$ \\
\hline Significant customization (26 - 50\% of the code) & $20 \%$ \\
\hline High level of customization (more than 50\% of the code) & $4 \%$ \\
\hline Full customization, individually developed, etc. & $1 \%$ \\
\hline No customisation & $9 \%$ \\
\hline
\end{tabular}

\subsection{Return on investment rate}

Increased efficiency and improved work with customers are the two areas in which companies most often feel benefits of the implementation of a new ERP system. What significantly differs from company to company and from ERP to ERP is the time in which these benefits become measurable so that the companies may claim that they recouped the invested capital (Table 2). 27\% had no return on investment, in $17 \%$ of the cases the payback period was 2 years, which is a good result minding that the average time is 30 months, while $24 \%$ were not sure whether the investment was recouped, which only indicates the lack of communication and clear objectives within such companies in terms of ERP implementation.

8 [19] Oracle ${ }^{\circledast}$ Database Concepts 11g Release 2 (11.2) E40540-01 July (2013)

9 [11] https://en.wikipedia.org/wiki/Application_programming_interface

10 [20] Panorama Consulting's (2104) ERP Report, Copyright: 2014 Panorama Consulting Solutions, 9 
Table 2: Return on investment rate ${ }^{11}$

\begin{tabular}{|l|c|}
\hline Payback period & $\%$ surveyed \\
\hline No benefits & $27 \%$ \\
\hline No data & $24 \%$ \\
\hline Less than 1 year & $5 \%$ \\
\hline 1 year & $8 \%$ \\
\hline 2 years & $17 \%$ \\
\hline 3 years & $5 \%$ \\
\hline 4 years & $8 \%$ \\
\hline 5 year or longer & $6 \%$ \\
\hline
\end{tabular}

\subsection{Global market research}

According to the results of an independent study conducted at the global level by Panorama Consulting Solutions, SAP is most often found among shortlisted manufacturers, followed by Oracle and Microsoft Dynamics. As regards the shortlisted ERPs that were most frequently selected by the users, Oracle is leading with $34 \%$, while Microsoft Dynamics and SAP won in $20 \%$ and $16 \%$ of the cases, respectively (Table 3).

Table 3: The most frequently selected manufacturers ${ }^{12}$

\begin{tabular}{|c|c|}
\hline The most frequently selected manufacturers & \% selection \\
\hline Oracle & $34 \%$ \\
\hline Microsoft & $20 \%$ \\
\hline SAP & $16 \%$ \\
\hline Epicor & $10 \%$ \\
\hline Others & $20 \%$ \\
\hline
\end{tabular}

\subsection{Implementation time}

The duration of an implementation project is directly linked to the scope of the project, available resources, functionalities of the selected software and their consistency with the needs of the company, as well as to the type of the selected solution.

Research has shown that the actual implementation time for an ERP system rarely coincides with the planned timeframe (Table 4: The reasons for exceeding deadlines). The largest discrepancy is seen in the implementation of Oracle -

\begin{tabular}{ll}
\hline 11 & Ibid., 16 \\
12 & Ibid., 17
\end{tabular}


about 4 months longer than planned. Both $\mathrm{SAP}^{13}$ and Microsoft Dynamics have an average of about 2 months beyond the planned deadlines. Microsoft Dynamics has the shortest overall implementation time ( 13 months), followed by SAP (17) and Oracle (18).

Table 4: The reasons for exceeding deadlines ${ }^{14}$

\begin{tabular}{|l|c|c|}
\hline The reasons for exceeding the deadlines & 2012 & 2011 \\
\hline Initial scope of the project was expanded & $29 \%$ & $17 \%$ \\
\hline Organisational problems & $20 \%$ & $14 \%$ \\
\hline Data problems & $17 \%$ & $14 \%$ \\
\hline Limited resources & $17 \%$ & $13 \%$ \\
\hline Training & $15 \%$ & $10 \%$ \\
\hline Technical problems & $14 \%$ & $7 \%$ \\
\hline Setting priorities during the project & $12 \%$ & $10 \%$ \\
\hline Unrealistic deadlines & $11 \%$ & $8 \%$ \\
\hline Software functionality issues & $4 \%$ & $8 \%$ \\
\hline
\end{tabular}

\section{Simulation and experimenting on the model - data synchronization cases}

Simulations ${ }^{15}$ and experimenting with the interface mode ${ }^{16}$ (generated with the aim of performing the necessary synchronization of the system and optimization of the processes and costs) are shown for two synchronization cases for which simulations on the model were defined and implemented, and which represent a cycle of experimenting with a view to presenting the capacities of the designed interface:

- The data which is entered in the ERP database (DB); it does not exist in the $C R M D B$ and

- Another case of synchronization showing the screens related to the data in the $D B \rightarrow$ it exists in the ERP DB; the change is made in the ERP DB and synchronized in the CRM DB.

An overview of all the cases of synchronization (possible operational scenarios) between the ERP and CRM DBs is the subject of a separate study. The data integration model within the interface model is a piece of designed and separately programmed application software.

\footnotetext{
13 [12] Implementing SAP Solutions on Amazon Web Services, Created by: Amazon Web Services LLC sap on-aws@amazon.com Version: 3 - April (2013)

14 [7] Clash of the Titans (2012), Copyright: 2012 Panorama Consulting Solutions, 12

15 [22] Robinson Stewart (2004):Simulation: the practice of model development and use / Stewart Robinson. p. cm. Includes bibliographical references and index. ISBN 0-470-84772-7 (pbk.), 37

16 Ibid
} 
The following principles were followed in implementing the simulations:

1) Consistency and integrity of the shared records (Partners, Items, and Services)

2) There is a clearly defined boundary between the CRM and ERP and all the synchronization processes.

Bearing in mind that detailed data on purchase, input and sales prices and their breakdown must be kept in the ERP system (DB containing all the key business data and documentation), this consolidated inventory is updated exclusively through the ERP applications in the ERP database, while the other subsystems (including the CRM and $\mathrm{SCM}^{17},{ }^{18}$ ) only use this data, which means that they do not add new data or change the existing data structure in this inventory.

As CRM operates over a separate database ${ }^{19}$, it is necessary to ensure its integration so that each item added or altered within this consolidated inventory is transferred to the CRM database as soon as it has been successfully processed in the ERP database, thus enabling continuous synchronisation of data in both databases (the key role of the interface is implemented here through simulating both cases of synchronisation).

This integration module should ensure the transfer of all the data necessary for the work of CRM, which represents a subset of the data necessary for ERP.

Situations when synchronizing the business partner registers between the CRM and ERP systems (Table 5)

Table 5: Select cases of synchronization

\begin{tabular}{|c|c|c|c|}
\hline $\begin{array}{c}\text { Simulation of the ERP } \rightarrow \text { CRM } \\
\text { synchronization }\end{array}$ & & & \\
\hline $\begin{array}{l}\text { Entered in the ERP base } \\
\text { Does not exist in the CRM base }\end{array}$ & $\begin{array}{c}\text { Immediately enters } \\
\text { the "Buyer" global } \\
\text { status }\end{array}$ & $\begin{array}{c}\text { Synchronized in the } \\
\text { CRM base with all } \\
\text { the data }\end{array}$ & $\begin{array}{l}\text { Changes not allowed } \\
\text { from the CRM }\end{array}$ \\
\hline \multicolumn{4}{|l|}{$\begin{array}{c}\text { Simulation of the ERP } \rightarrow \text { CRM } \\
\text { synchronization }\end{array}$} \\
\hline $\begin{array}{l}\text { Changed in the ERP base } \\
\text { Exists in the CRM base }\end{array}$ & $\begin{array}{l}\text { Already in the global } \\
\text { status "Buyer" }\end{array}$ & $\begin{array}{c}\text { Synchronized in the } \\
\text { CRM base with all } \\
\text { the data }\end{array}$ & $\begin{array}{l}\text { Changes not allowed } \\
\text { from the CRM }\end{array}$ \\
\hline
\end{tabular}

Source: the authors

17 [18] Monk Ellen F. University of Delaware, Bret J. Wagner Western Michigan University (2013): "Concepts in enterprise resource planning", Australia, United Kingdom , United States, ISBN-13: 978-1-111- 82040-4 , 23

18 [2] Bąkowski, M. (2002):C-commerce. Would mixing ERP, CRM, e-Procurement and SCM be an efficient strategy for the future? , 107-114.

19 [15] Langer Arthur M.:Analysis and Design of Information Systems, Third Edition, Library of Congress Control Number: 2007928317 ISBN 978-1-84628-654-4 e-ISBN 978-1-84628-655-1, 127, 176 
If a new partner appears directly in the sales (ERP) processes, he is entered in the partner register in the ERP base and synchronized with the CRM, while all further data changes are effected through the ERP applications within the base. It is prohibited to change partner data through the CRM applications.

In the operational sense, all the statuses are shown in the screens resulting from the previous statuses in the ERP and CRM DBs and the new statuses after the changes are made to the partners; the principle is as follows:

- A new contact is created in the ERP DB, and after the synchronization, it is displayed in the $C R M D B$

- A change is made in the ERP DB with the overview of the status before and after the change, i.e. the before/after status in the CRM DB.

The simulation processes were conducted through experimenting on certain data groups (i.e. entity attributes) considered to be most frequently changed when it comes to consumers, as a result of the business needs adjustments and cost optimization in dealing with consumers.

The clients who used the interface in the test phase have subsequently confirmed in the implementation phase that the interface efficiently performs the data integration, that it is optimally adjusted to the needs of the user, that the synchronisation processes are simple and properly harmonised and that they reduce the amount of unnecessary operational procedures and processes, on the one hand, and ensure the reduction of backlinks between the DBs, operational costs and the level of complexity of business processes, on the other.

Figure 3: Creating a new contact (ERP database)

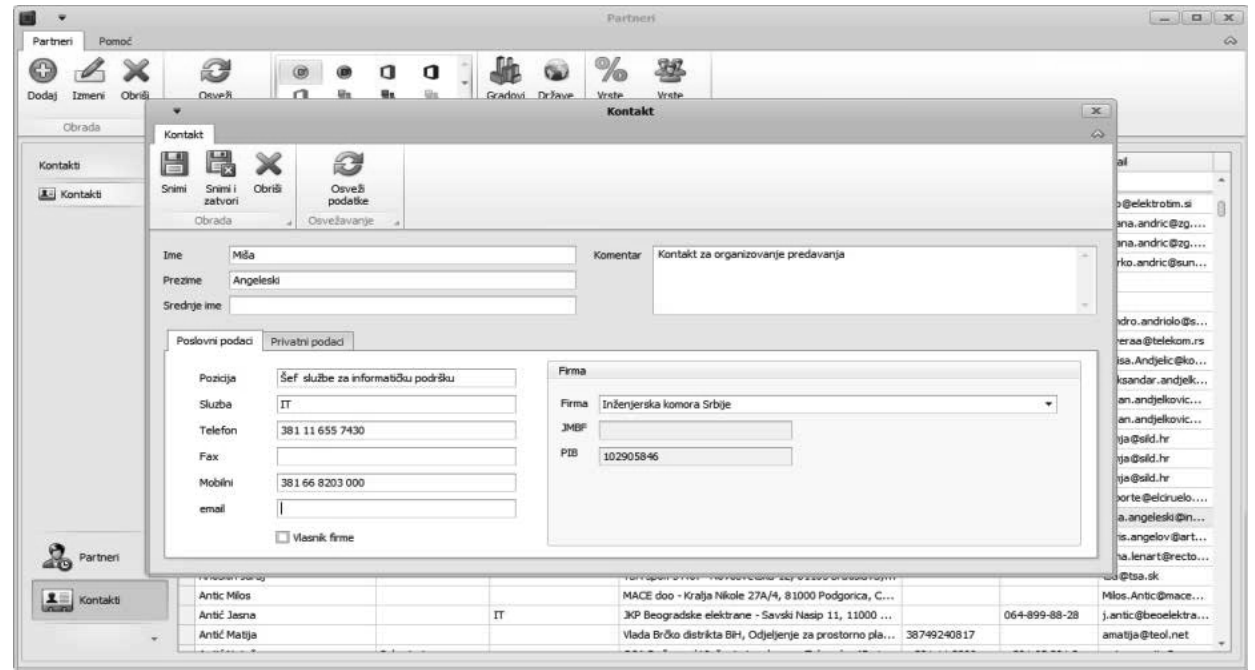

Source: the authors 
Figure 4: The new contact after synchronization (CRM database)

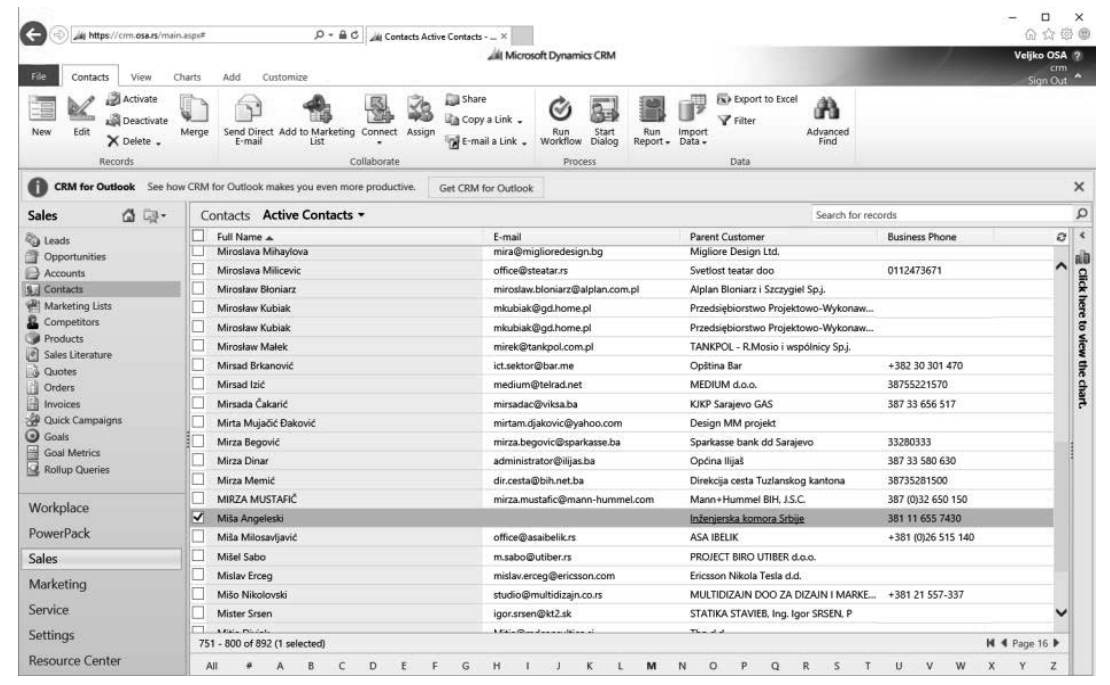

Source: the authors

Figures 3 and 4 represent the results of the simulation and experimenting on the model, i.e. the simple processes and procedures illustrating the data integration process and their links to the DBs established through the synchronization process.

For instance, on the ERP side we created a new contact using the "Partners" application (Figure 3). After the contact has been created on the ERP side, the service performs synchronization with the CRM DB, and the created contact can be seen in the CRM DB (Figure 4).

\section{Applying the data integration model with a view to reducing consumer related costs}

The data integration model is logically checked through the Web services ${ }^{20}$ created and used during the test phase and later in the pilot implementation phase in order to show its benefits for both sides - the designer and the user of the API model, and to verify the implemented technology ${ }^{21}$ and architecture.

20 [30] WS-BPEL (Web Services Business Process Execution Language) - In 2003 IBM and Microsoft combined WSFL and Xlang into BPEL4WS and initiated the standardization process with OASIS. OASIS published BPEL4WS as WS-BPEL in accordance with the rules of the WS- ${ }^{*}$ standard designation.

21 [9] Davenport, T. H. (1998):Putting the Enterprise into the Enterprise System. Harvard Business Review, 76(4), 121-131. 
The purpose of using the Web service is to write a program for the user, which the WS may call dynamically and functionally define the architecture for the client, his work, and the operational environment within the designed and programmed API (e.g. Web services in the MS Office environment).

The SOA (Service Oriented Architecture ${ }^{22}$ ) technology ensures the ability (as used in the API structure) of calling the Web services and their integration ${ }^{23}$ within the API applications (database synchronization processes, i.e. the key structures for updating all status changes that may occur during the data synchronisation).

In designing the program subsystem the database was represented by the WCF (Windows Communications Foundation) framework and the dot.net environment ${ }^{24}$, and the key challenge was to define WSDL and endpoint information for the given Web services, i.e. to ensure the independence of WS from the actual information system.

The integrated programme structure of the interface, the designed and programmed WS, the Web service generation mechanisms and the Web service addressing define the two interoperable structures that transmit the information; they are typically based on a transport protocol, a messaging system, and the new internet technologies ${ }^{25}$.

The aim of the program system is to join the interoperable structures (the endpoint references and the headers of messages exchanged in the API environment) into a single format that can be processed independently from the data transport and the API application.

The ERP and CRM database synchronization processes (a more complex scenario would involve the synchronization of all three databases: ERP, CRM and $S C M^{26}$ ) are designed on the basis of simple logical simulations showing the data integration processes and verifying the efficiency of the designed interface ${ }^{27}$. Based on the dynamic updating of the data contained in the ERP and CRM databases, and in accordance

22 [10] Hansen, Mark D.: SOA Using Java Web Services / Mark D. Hansen. p. cm. Includes bibliographical references and index. ISBN 978-0-13-044968-9 (pbk.: alk. paper) 1. Web services. 2. Java (Comput0er program language) 3. Computer network architectures, 22

23 [25] Tanenbaum, Andrew S. (2010): Computer networks / Andrew S. Tanenbaum, David J. Wetherall. -- 5th ed. p. cm. Includes bibliographical references and index. ISBN-13: 978-0-13- 212695-3 (alk. paper) ISBN-10: 0-13-212695-8 (alk. paper), 29

24 [29] WCF Windows Communication Foundation, www.tutorialspoint.com,(2014) by Tutorials Point (I) Pvt. Ltd, http://www.facebook.com.tutorialspoinindia, www.twitter.com.tutorialspoint, 10, 18, 67, 71, 78

25 [24] Sofronijević Adam ${ }^{1}$, Milićević Vesna ${ }^{2}$, Marković Aleksandar ${ }^{3}$, University of Belgrade, University Svetozar Marković Library, ${ }^{2,3}$, University of Belgrade, Faculty of Organizational Sciences, Serbia, Management 2015/74, New Internet Business Initiatives in the Context of Change Management, UDC:005.336.5:004 004.738.5 005.591:005.21 DOI:10.7595/management.fon.2015.0007, 38, 42

26 [6] Chopra, S., and Meindl, P. (2010): Supply Chain Management: Strategy, Planning, and Operation. 4rd ed. Boston, MA: Pearson Education.

27 [5] Chong Kwong Chen (2011):A middleware integrating ERP, CRM and supply chain management system using service oriented architecture, Faculty of Computer Science and information technology University of Malaya Kuala Lumpur , 79, 100 
with the synchronization and security logic ${ }^{28}$, WSs are defined and implemented so as to ensure all the control and operational data necessary for consumer management.

- The services used for the data synchronization between the ERP and CRM databases are programmed in the WCF environment.

- For the purposes of this study, two WCF services were created and hosted as win services.

- One of the services was installed on the ERP side to monitor the ERP database, while the other was installed on the CRM side to monitor the CRM database. The cashed data is contained in another database accessible by both services.

- The services operate in the following manner:

- When the services are started, the reading is performed by all the partners/ contacts in the ERP database (which are already present in this database and have to be inherited by the CRM database), an xml file is created (Figure 6) separately for the partners and for the contacts, and the CRM service methods are called to forward the $\mathrm{xml}^{29}$ files. Afterwards, each time the services pass through the database only the data about the partner/contact that has been added or changed in the database will be read (the data is obtained by monitoring certain tables in the database); likewise, the $\mathrm{xml}$ file will be created and the CRM service methods will be called if there have been any changes.

- If the CRM service fails to add or change the data in the CRM database, the ERP service will place a specific $\mathrm{xml}$ file with the information about the cached data in the database visible to both the ERP and the CRM systems. Each time the ERP service passes through, it will also check the cashed data and forward the saved xml files, if any, to the CRM service. If during this pass through the database CRM successfully completes the adding/changing of the data from the $\mathrm{xml}$ file, it will signal the ERP service to delete the xml file from the cache, and if not, the ERP service will be notified about it and the $\mathrm{xml}$ file will not be deleted.

- The CRM service takes over the $\mathrm{xml}^{30}$ file and performs the adding or changing of the partner/contact, depending on whether the partner/contact exists in the CRM base as per the given criteria. If CRM fails to execute the above actions, it will send information about that to the ERP service, and the service will store the $\mathrm{xml}$ file ${ }^{31}$.

28 [17] Martino, L. D., \& Bertino, E. (2009):Security for Web Services: Standards and Research Issues. International Journal Of Web Services Research,6(4), 48-74. doi:10.4018/jwsr.2009071303

29 [26] Tidwell Doug, Snell James, Kulchenko Pavel (2001): Programming Web Services with SOAP, O’Reilly, First Edition, ISBN: 0-596-00095-2, 216, 21, 170

30 [31] XPDL (XML Process Definition Language) - a format for exchanging business processes definitions between two different products (e.g. the OMG (Object Management Group) modeling and management tools). It is defined as an XML Schema for specifying the descriptive part of the business process.

31 [27] Towards The Semantic WEB Ontology-driven Knowledge Management Edited by Dr. John Davies British Telecommunications plc Professor Dieter Fensel University of Innsbruck, Austria, and Professor 
Figure 5: Structure of the XML file

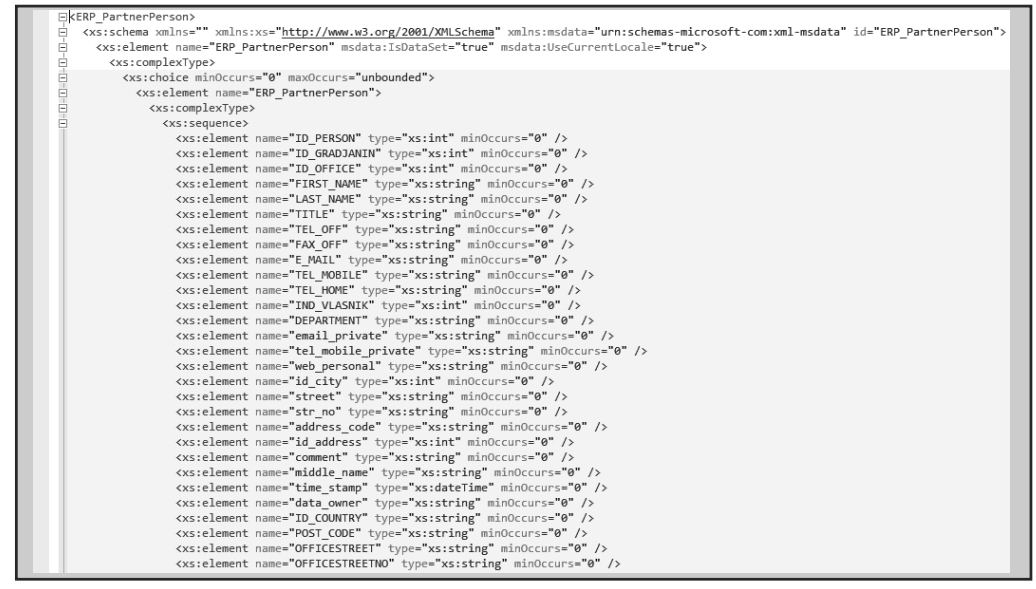

Source: the authors

\section{Evaluation of the model's implementation and the study results}

The evaluation of the study results (the quality of the generated interface and its utility) was defined by the survey (online interview - email/web); the respondents used the pilot version of the interface (application programme) and provided answers to 10 key questions (it should be noted that several sets of questions were prepared for various personnel in the IT hierarchy: SW company CEOs as the top management, middle management, managers of operations, and specialists directly involved in designing, programming, web programming, and communications and networks). The obtained answers served as the basis for the analyses structured on the Likert scale ${ }^{32}$ : SA - strongly agree, A - agree, $\mathrm{N}$ - neutral (neither agree nor disagree), D - disagree, SD - strongly disagree. The number of respondents exceeded 100 but it was reduced to a sample of 55, whose structure included various IT management and operations staff (including SW company CEOs, managers of certain IT departments, top level managers, middle managers, and IT operations managers and designers and programmers).

The results of the e-survey/web survey are arranged systematically in Table 6 , showing the number of obtained answers to each question and expressing it as percentage of the total amount (defective and incomplete answers were discarded so the number of respondents was reduced to 55, as reflected in the data shown in the table).

Frank van Harmelen Vrije Universiteit, Amsterdam, Netherlands JOHN WILEY \& SONS, LTD, 17, 49

32 [16] Likert, R. (1931):A technique for the measurement of attitudes. Archives of Psychology. New York: Columbia University Press. 22 
Table 6: The data table structured from the body of information obtained through the e-survey/web survey

\begin{tabular}{|c|c|c|c|c|c|c|c|c|c|c|}
\hline & Questions & & & & & & & & & \\
\hline Likert scale & P.1 & P.2 & P.3 & P.4 & P. 5 & P.6 & P.7 & P.8 & P.9 & P.10 \\
\hline SA = strongly agree & 6 & 9 & 22 & 20 & 12 & 1 & 10 & 30 & 22 & 19 \\
\hline$\%$ & $10.91 \%$ & $16.36 \%$ & $40.00 \%$ & $36.36 \%$ & $21.82 \%$ & $1.82 \%$ & $18.18 \%$ & $54.55 \%$ & $40.00 \%$ & $34.55 \%$ \\
\hline A चgree & 28 & 25 & 16 & 18 & 7 & 10 & 2 & 15 & 20 & 31 \\
\hline$\%$ & $50.91 \%$ & $45.45 \%$ & $29.09 \%$ & $32.73 \%$ & $12.73 \%$ & $18.18 \%$ & $3.64 \%$ & $27.27 \%$ & $36.36 \%$ & $56.36 \%$ \\
\hline yes/no & 6 & 14 & 10 & 0 & 34 & 44 & 40 & 0 & 10 & 0 \\
\hline$\%$ & $7.27 \%$ & $25.45 \%$ & $18.18 \%$ & $0.00 \%$ & $61.82 \%$ & $80.00 \%$ & $72.73 \%$ & $0.00 \%$ & $18.18 \%$ & $0.00 \%$ \\
\hline D = disagree & 11 & 4 & 1 & 10 & 2 & 0 & 2 & 0 & 3 & 5 \\
\hline$\%$ & $20.00 \%$ & $7.27 \%$ & $1.82 \%$ & $18.18 \%$ & $3.64 \%$ & $0.00 \%$ & $3.64 \%$ & $0.00 \%$ & $5.45 \%$ & $9.09 \%$ \\
\hline$S D=$ strongly disagree & 4 & 3 & 6 & 7 & 0 & 0 & 1 & 10 & 0 & 0 \\
\hline$\%$ & $10.91 \%$ & $5.45 \%$ & $10.91 \%$ & $12.73 \%$ & $0.00 \%$ & $0.00 \%$ & $1.82 \%$ & $18.18 \%$ & $0.00 \%$ & $0.00 \%$ \\
\hline & $100.00 \%$ & $100.00 \%$ & $100.00 \%$ & $100.00 \%$ & $100.00 \%$ & $100.00 \%$ & $100.00 \%$ & $100.00 \%$ & $100.00 \%$ & $100.00 \%$ \\
\hline
\end{tabular}

Source: the authors

The field data was statistically processed and Cronbach's alpha ${ }^{33}$ was calculated, which needed to be $>=\mathbf{0 . 7}$ in order to show the consistency of the analysed data. Based on the calculation (Cronbach's alpha $=0.748474$ ) it has been shown that the data is consistent and reliable and that the obtained results about the generated interface and its functionalities (Table 6) can be considered accurate and reliable. The result obtained by analysing the survey (Table 7) confirms the utility of the designed interface and shows that the integration through the model of independent databases (ERP, CRM, and SCM) and the integration functionalities have yielded the required level of efficiency of the generated interface, i.e. that all the envisaged technical and operational tasks were realised and that an efficient system of controlling the synchronisation processes of independent databases was created.

\section{Questions in the e-mail/web survey (structure of the survey)}

q.1 = domain: Management and strategic planning: Question 1: Does the API management and strategic planning (interface application ensuring data integration) have an impact on the profitability of IT companies? Answer: 12345 q.2 = domain: Choice of ERP/CRM/SCM: Question 2: Does the choice of the ERP/ $\mathrm{CRM} / \mathrm{SCM}$ application materially determine the functionality of API? Answer: 12345 q.3 = domain: Management support: Question 3: Does management support increase the effects of the implemented API?

Answer: 12345

33 [8] Cronbach Lee J. University of Illinois Psychometrika-Vol. 16, No. 3 Sep. (1951)

Coefficient alpha and the internal structure of tests 299, 301 
q.4 = domain: Management and implementation methods: Question 4: Do management and implementation have an impact on the optimal use of API?

Answer: 12345

9.5 = domain: Financial management: Question 5: Does the IFACE implementation facilitate the financial management? Answer: 12345

p.6 = domain: Network resource management: Question 6: Does the IFACE implementation optimise the network resource management? Answer: 12345

q.7 = domain: Technical complexity: Question 7: Does the IFACE implementation increase technical complexity in dealing with customers? 12345

$9.8=$ domain: The manner of system and business management: Question 8: Does the IFACE implementation affect the manner of system and business management? Answer: 12345

9.9 = domain: Staff selection, arrangement and participation: Question 9: Does the IFACE implementation affect the selection, arrangement and participation of the staff in the customer relationship management? Answer: 12345 q.10 = domain: Owner relations in management: Question 10: Does the IFACE implementation affect the owner relations in the customer relationship management? Answer: 12345

Legend: $5=\mathbf{S A}=$ strongly agree, $4=\mathbf{A}=$ agree, $3=$ yes $/$ no (neither agree nor disagree), $2=\mathbf{D}=$ disagree, $1=\mathbf{S D}=$ strongly disagree

Table 7: Results of the study obtained by the email/web survey

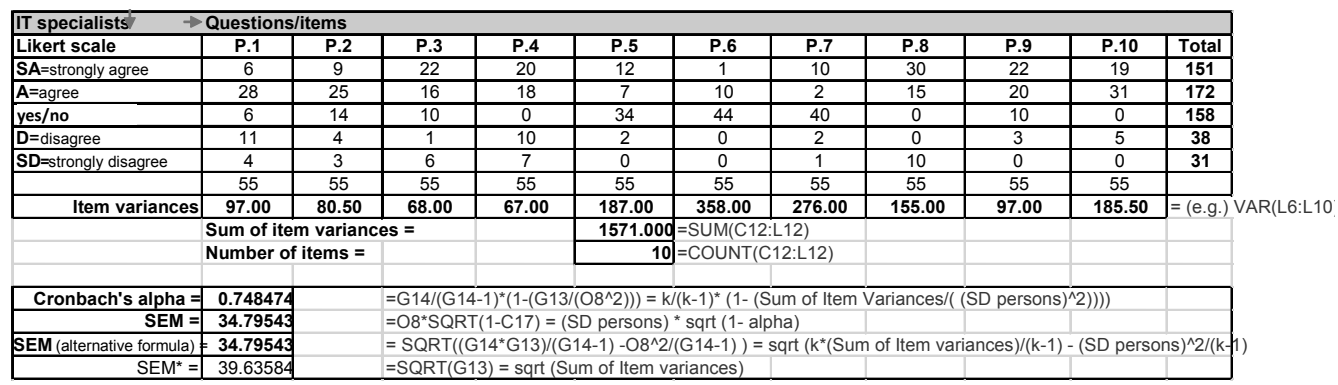

\begin{tabular}{|lrl|}
\hline Statistics: Likert scale & & \\
Mean value & 110.000 & $=\operatorname{AVERAGE}(\mathrm{M6}: \mathrm{M} 10)$ \\
SD & 69.379 & $=\operatorname{STDEV}(\mathrm{M} 6: \mathrm{M} 10)$ \\
Variance & 4813.500 & $=08^{\wedge} 2$ \\
\hline
\end{tabular}

Source: the authors

The results obtained in the survey indicate the importance of the three key sets of processes: organizational, managerial and information/technological, which determine the quality of the generated and implemented API, as shown by the marks given by IT specialist to the survey questions. The results of the survey are 
a reliable measure for evaluating the IT quality of the projected and programmed API, i.e. its features and functionalities that facilitate the customer relationship management and contribute to an optimal regime of controlling the functions and overall data integration of the generated models' databases within the given $\mathrm{ERP} \rightarrow \mathrm{CRM}$ structure and the more complex ERP $\rightarrow \mathrm{CRM} \rightarrow \mathrm{SCM}^{34}$ structure.

\section{Conclusions}

The need for changes in the business organisation, implemented technologies, the objectives and content of the customer relationship policy were taken as the starting point of this study and the basis for analysing the structure of the business system, management mechanisms, and e-business integration model with the aim of optimising relations with customer and the business system as a whole; the study analysed the inconsistencies and lack of synchronisation between the parent IS and the ERP/CRM systems.

The changes and significant adaptations to the new marketing and IT technologies have led to modifications in the business models and software, causing increased reliance on e-business/e-commerce models and introducing various multi-layered internet technologies for the purposes of enabling more efficient business operations and meeting the ever more complex demands of customers/ consumers, which are the drivers of business success and the measure of profitability, productivity and effectiveness of any business system.

Consumers often indicate that they want consistency, proactive approach and swift response from their suppliers. The key to responsiveness and management actions is based on CMP - customer management processes, and on differentiating between consumer behaviour and brand loyalty (conditionally speaking, loyalty to the business system servicing the needs of consumers), developing in a practical manner optimal relations with consumers that are conditionally generated by certain priorities and ICT resources that serve as the basis for evaluations, forecasts and statistics of relevance for the decision making processes.

The generated API model is an important operational and strategic tool that is relatively independent of the complexity of business system, i.e. of the implemented application systems; as such, it represents a model for optimising the independent ERP, CRM and SCM systems, or, in a more complex variant, for controlling the databases, information and message exchange, and processes and errors generated within individual systems or transferred into the API structure, where all the statuses and inconsistencies are finally and irrevocably resolved.

The data integration system and the generated API have provided a series of operative solutions applied to improve the business system functionality and

[1] Almotairi, M. (2009):A framework for successful CRM implementation. European and Mediterranean Conference on Information Systems (2009), 1-14). Crowne Plaza Hotel, Izmir.

Vol. 13, № 3 2016: 243-262 
reduce costs; they placed under control the key strategic and operational processes targeted at customers, but also all the other process and application needs of the IT industry business system as such.

The offered API solutions enable sales control and control mechanisms of the IT SW module integration of both the ERP and the CRM system, in particular of all the key data on customers created through the data integration model (the functions and application solutions of the generated API); they ensure efficiency of sales control, establish new sales control e-mechanisms, and provide new tools for predicting the consumer behaviour and their purchases.

The API solutions serve as a basis for securing efficiency of the sales network and value-added products and services, especially through the use of cloud technology $y^{35}$. The generated API introduces significant improvements to the control of individual functions of the ERP and CRM systems, and also of the integrated data chains generated through database control and data exchange in the processes of entering, updating, sending and receiving the messages that regulate the status of errors emerging in the communication between the ERP and CRM systems in the integrated environment. Special effects of the Interface are realised through the data integration and exchange implemented through the sales networks and the increased speed of data exchange between the central locations and the servers, i.e. branches/business units, which ensures local coverage of the needs in the sales network and enables the introduction of new services in the business and customer relationship domains, i.e. various services at the level of certain communication channels (FB, Twitter, social networks, mobile channels, and other internet channels increasing the scope of virtual business).

The integrated system control parameters are defined in the basic API structure. They control (basic and modified) ERP $\rightarrow$ CRM and the more complexly structured model of ERP $\rightarrow$ SCM $\rightarrow$ CRM, which includes the supply chain management as an extension of the control of the market factors and parameters (the API that includes the individual databases and generates a separate database created through the exchange). Additionally, the data integration model includes error control by creating the necessary xml files, and defines a number of parameters and control processes that provide a basis for the integrated system management (pre-sales and sales processes, items, identifiers, database exchange mechanisms) ensuring all the data necessary for the strategic and operational management, i.e. for the vertical and horizontal control and interventions in the business system with the aim of overall business optimisation based on the designed and programmed API.

\footnotetext{
35 [4] Caron, E., Desprez, F., Loureiro, D., \& Muresan, A. (2009): Cloud Computing Resource Management through a Grid Middleware: A Case Study with DIET and Eucalyptus. CLOUD:(2009) IEEE International conference on cloud computing, 151-154, 345 E 47TH ST, NEW YORK, NY 10017 USA: IEEE.
} 


\section{Literature:}

[1] Almotairi, M. (2009): A framework for successful crm implementation, European and Mediterranean Conference on Information Systems 2009, 1-14). Crowne Plaza Hotel, Izmir.

[2] Bąkowski, M. (2002): C-commerce. Would mixing ERP, CRM, e-Procurement and SCM be an efficient strategy for the future?, 107-114.

[3] Bradford Marianne (2015): Modern ERP, Select, Implement \& use today's advanced business systems, Raleigh, NC, 156

[4] Caron, E., Desprez, F., Loureiro, D., \& Muresan, A. (2009):Cloud Computing Resource Management through a Grid Middleware: A Case Study with DIET and Eucalyptus. CLOUD:2009 IEEE International conference on cloud computing (pp. 151-154). 345 E 47TH ST, NEW YORK, NY 10017 USA: IEEE.

[5] Chong Kwong Chen (2011):A middleware integrating ERP, CRM and supply chain management system using service oriented architecture, Faculty of Computer Science and information technology University of Malaya Kuala Lumpur, 79, 100

[6] Chopra, S. and Meindl, P. (2010):Supply Chain Management: Strategy, Planning, and Operation. 4rd ed. Boston, MA: Pearson Education.

[7] Clash of the Titans (2012), Copyright: 2012 Panorama Consulting Solutions, 12

[8] Cronbach Lee, University of Illinois, Psychometrika -Vol. 16, No. 3 Sep. (1951) Coefficient alpha and the internal structure of tests, 299, 301

[9] Davenport, T. H. (1998):Putting the Enterprise into the Enterprise System. Harvard Business Review, 76(4), 121-131.

[10] Hansen, Mark D.: SOA Using Java Web Services / Mark D. Hansen. p. cm. Includes bibliographical references and index. ISBN 978-0-13-044968-9 (pbk. : alk. paper) 1. Web services. 2. Java (Comput0er program language) 3. Computer network architectures, 22

[11] https://en.wikipedia.org/wiki/Application_programming_interface

[12] Implementing SAP Solutions on Amazon Web Services Created by: Amazon Web Services LLC sap- on-aws@amazon.com Version: 3 - April (2013)

[13] Jovanović, M., Rankov, S. (2012): Primena elektronskog poslovanja u upravljanjusloženimsistemima, ISBN 9786-7038-054-7, COBISS.SR-ID 191422220, Published by Post of Serbia Public Enterprise, 44

[14] Kalakota\& Robinson (2001):E-Business 2.0: Roadmap for Success, ISBN-10: 0-20172165-1, ISBN-13: 978-0-201-72165-2, 125, 131;

[15] Langer Arthur : Analysis and Design of Information Systems, Third Edition, Library of Congress Control Number: 2007928317 ISBN 978-1-84628-654-4 e-ISBN 978-184628-655-1, 127, 176

[16] Likert, R. (1931):A technique for the measurement of attitudes. Archives of Psychology. New York: Columbia University Press. 22

[17]Martino, L. D., \& Bertino, E. (2009): "Security for Web Services: Standards and Research Issues”, International Journal Of Web Services Research, 6(4), 48-74. doi:10.4018/jwsr.2009071303 
[18] Monk Ellen, University of Delaware, Wagner Bret, Western Michigan University (2013):Concepts in enterprise resource planning, Australia, United Kingdom , United States, ISBN-13: 978-1-111- 82040- 4, 23

[19] Oracle ${ }^{\odot}$ Database Concepts 11g Release 2 (11.2) E40540-01 July (2013)

[20] Panorama Consulting's (2104) ERP Report, Copyright: 2014 Panorama Consulting Solutions, 9 Panorama Consulting's (2104) ERP Report, Copyright: 2014 Panorama Consulting Solutions, 16 Panorama Consulting's (2104) ERP Report, Copyright: 2014 Panorama Consulting Solutions, 17

[21] Rashid, Hussain, \& Patrick, (2002): Enterprise Resource Planning: Global Opportunities \& Challenges, ISBN 1-930708-36-X (cloth), eISBN 1-59140-025-2, 215).

[22] Robinson Stewart (2004):Simulation: the practice of model development and use / Stewart Robinson p.cm. Includes bibliographical references and index. ISBN 0-470-84772-7 (pbk.), (2004), 37

[23] Shields Murrell (2001):E-business and ERP rapid implementation and project planning, by John Wiley \& Sons, Inc., ISBN 0-471-40677-5, 10

[24] Sofronijević Adam¹, Milićević Vesna ${ }^{2}$, Marković Aleksandar ${ }^{3}$, University of Belgrade, Svetozar Marković University Library ${ }^{2,3}$, University of Belgrade, Faculty of Organizational Sciences, Serbia Management 2015/74, New Internet Business Initiatives in the Context of Change Management UDC:005.336.5:004 004.738.5 005.591:005.21 DOI:10.7595/management.fon.2015.0007, 38, 42

[25] Tanenbaum Andrew S. (2010): Computer networks / Andrew S. Tanenbaum, David J. Wetherall. -- 5th ed. p. cm. Includes bibliographical references and index. ISBN13: 978-0-13- 212695-3 (alk. paper) ISBN-10: 0-13-212695-8 (alk. paper), 29

[26] Tidwell Doug, Snell James, Kulchenko Pavel(2001): Programming Web Services with SOAP, Publisher: O'Reilly, First Edition, ISBN: 0-596-00095-2, 216, 21, 170

[27] Towards The Semantic WEB Ontology-driven Knowledge Management, Edited by Dr John Davies, British Telecommunications plc, Professor Dieter Fensel, University of Innsbruck, Austria, and Professor Frank van Harmelen, Vrije Universiteit, Amsterdam, Netherlands JOHN WILEY \& SONS, LTD, 17, 49

[28] Tuzhilin, A. (2012):Customer relationship management and Web mining: the next frontier. Data Mining And Knowledge Discovery, 24(3, SI), 584-612. doi:10.1007/ s10618-012-0256-Z

[29] WCF Windows Communication Foundation, www.tutorialspoint.com,(2014) by Tutorials Point (I) Pvt. Ltd,http://www.facebook.com.tutorialspoinindia,www. twitter.com.tutorialspoint, 10, 18, 67, 71, 78

[30] WS-BPEL (Web Services Business Process Execution Language) - 2003. IBM and Microsoft combined WSFL and Xlang into BPEL4WS and initiated the standardization process with OASIS. OASIS published BPEL4WS as WS-BPEL in accordance with the rules of the WS- ${ }^{*}$ standard designation.

[31] XPDL (XML Process Definition Language) - a format for exchanging business processes definitions between two different products (e.g. the OMG (Object Management Group) modeling and management tools). It is defined as an XML Schema for specifying the descriptive part of the business process.

[32] Yajun Zeng (2010): Risk Management for Enterprise Resource Planning System Implementations in Project Based Firms, 9 
ŽELJKO TOMIĆ, MSc, BSc IN ELECTRICAL ENGINEERING

Director at OSA - Računarski inženjering doo

MIHAILO JOVANOVIĆ, Ph.D., BSc In EleCtrical ENGINEERING

Executive Director at PTT Serbia Public Enterprise

\section{SINHRONIZACIJA PODATAKA I SMANJENJE TROŠKOVA UPOTREBOM RAZVOJNOG OKRUŽENJA U SISTEMU ZA UPRAVLJANJE ODNOSIMA SA POTROŠAČIMA}

Istraživanja su pokazala da 51\% svih ERP implementacija prouzrokuje neki vid problema u poslovanju tokom eksploatacione faze. Uprkos svim naporima da se poveća efikasnost i poboljšaju poslovni procesi, mnoge organizacije dolaze do zaključka da, kada pređu na novi ERP sistem, nisu u mogućnosti da izvršavaju neke od osnovnih poslovnih operacija ( $\mathrm{u}$ fazi preuzimanja podataka i u operativnim obradama), kao što je, na primer, izdavanje robe iz magacina. ERP implementacije su prečesto praćene tehničkim $i$ organizacionim problemima koji mogu uzrokovati probleme u funkcionisanju poslovnog sistema. Organizacioni problemi su mnogo češći uzrok i zbog toga je veoma važno precizno odraditi fazu analize poslovnih procesa kao i završno testiranje.

$\mathrm{Na}$ osnovu analize ERP (Enterprise Resource Planning), CRM(Customer Relationship Management) i SCM(Supply Chain Management) modela elektronskog poslovanja (EP) najvećih proizvodjača softverskih aplikacija, definisana su uska grla i nedostaci koji su bili karakterisitčni za implementacije modela (na bazi izabranog uzorka kiljenata) i ustanovljeno je da postoje odredjene neuskladjenosti i programski problemi na relaciji IS kompanije i implementirani ERP/CRM ili SCM modeli. Problemi koji su uočeni, poslužili su kao osnova za projektovanje i programiranje aplikativnog interfejsa (API), specijalizovane namene za rešavanje odredjenih aplikativnih potreba kompanija, odnosno, nedovoljne sinhronizacije baza podataka i drugih informatičkih resursa. Projektovan je i programiran API, koji rešava probleme neuskladjenosti i sinhronizacije $i$ smanjuje troškove poslovanja. Testiran je i kao pilot aplikacija na izabranim kompanijskim IS koje koriste ERP/CRM sisteme za podršku poslovanju. U radu je prikazan proces sinhronizacije BP ERP/CRM i izvršeno testiranje kvaliteta API rešenja na bazi programirane web ankete, odnosno statističke obrade i dobijenih rezultata ankete, koja dokumentuje kvalitet ponudjenih rešenja i potvrdjuje uspešnu primenu API rešenja.

Ključne reči: upravljanje resursima preduzeća (ERP), upravljanje odnosima sa potrošačima (CRM), interfejs, veb servisi, API, poslovni procesi, system za upravljanje vazama podataka, baze podataka

Vol. 13, № 3 2016: 243-262 